\title{
Efficacy and safety of fixed-combination bimatoprost/timolol ophthalmic solution
}

LETTER

This article was published in the following Dove Press journal:

Patient Preference and Adherence

26 June 2017

Number of times this article has been viewed

\author{
Suk Bae Moon' \\ Sang Beom Han² \\ 'Department of Surgery, Kangwon \\ National University Hospital, \\ Kangwon National University \\ Graduate School of Medicine, \\ Chuncheon, Korea, ${ }^{2}$ Department of \\ Ophthalmology, Kangwon National \\ University Hospital, Kangwon \\ National University Graduate School \\ of Medicine, Chuncheon, Korea
}

\section{Dear editor}

We read, with interest, the article by Sun et $\mathrm{al}^{1}$ entitled "Patient satisfaction with fixed-combination bimatoprost/timolol ophthalmic solution: a survey study in patients with glaucoma in China". This observational multicenter study with excellent design was undoubtedly well conducted, and the authors successfully demonstrated that fixed-combination bimatoprost/timolol ophthalmic solution can provide the glaucoma patients with improved satisfaction. ${ }^{1}$

However, we would like to point out that the measurement of intraocular pressure (IOP) would have been necessary for better evaluation of IOP lowering the efficacy of the regimen. Considering that normal-tension glaucoma is more prevalent than high-tension glaucoma in Asian patients, ${ }^{2}$ subjective assessment of IOP control could sometimes be inaccurate. IOP measurement in individual patients might be difficult due to this study including a large population residing in multiple areas. In this situation, review of medical records or survey with the participating physicians could be helpful.

Moreover, for more precise evaluation of tolerance and comfort, assessment of subjective symptom indices, such as ocular surface disease index and visual analog scale, would be beneficial. ${ }^{3}$ If possible, investigation of ocular surface signs using indices including tear film break-up time, Schirmer test and fluorescein stain score would also be helpful, considering that ocular surface disease is associated with increased severity of glaucoma and higher exposure to benzalkonium chloride. ${ }^{4}$

In addition, follow-up period of 1-3 months could be relatively short for the development of side effects. Therefore, we believe further studies with long-term follow-up including more precise parameters would be helpful for elucidation of efficacy and safety of fixed-combination bimatoprost/timolol ophthalmic solution.

\section{Disclosure}

The authors report no conflicts of interest in this communication.

\section{References}

1. Sun X, Lin M, Duan X, Zhang C, Ming J. Patient satisfaction with fixed-combination bimatoprost/timolol ophthalmic solution: a survey study in patients with glaucoma in China. Patient Prefer Adherence. 2017; $11: 845-852$.

2. Cho HK, Kee C. Population-based glaucoma prevalence studies in Asians. Surv Ophthalmol. 2014; 59(4):434-447.

3. Han SB, Hyon JY, Wee WR, Lee JH, Lee YJ, Yun PY. Reduced corneal sensitivity in patients with primary Sjogren's syndrome. Acta Ophthalmol. 2010;88(7):e277-e278.

4. Skalicky SE, Goldberg I, McCluskey P. Ocular surface disease and quality of life in patients with glaucoma. Am J Ophthalmol. 2012;153(1):1-9. e2. 
Dove Medical Press encourages responsible, free and frank academic debate. The content of the Patient Preference and Adherence 'letters to the editor' section does not necessarily represent the views of Dove Medical Press, its officers, agents, employees, related entities or the Patient Preference and Adherence editors. While all reasonable steps have been taken to confirm the content of each letter, Dove Medical Press accepts no liability in respect of the content of any letter, nor is it responsible for the content and accuracy of any letter to the editor.

Patient Preference and Adherence

Dovepress

\section{Publish your work in this journal}

Patient Preference and Adherence is an international, peer-reviewed, open access journal that focuses on the growing importance of patient preference and adherence throughout the therapeutic continuum. Patient satisfaction, acceptability, quality of life, compliance, persistence and their role in developing new therapeutic modalities and compounds to optimize

clinical outcomes for existing disease states are major areas of interest for the journal. This journal has been accepted for indexing on PubMed Central. The manuscript management system is completely online and includes a very quick and fair peer-review system, which is all easy to use. Visit http://www. dovepress.com/testimonials.php to read real quotes from published authors.

Submit your manuscript here: http://www.dovepress.com/patient-preference-and-adherence-journal 